\title{
Innovations of Engineering Company and Competitiveness in the Mining Equipment Market
}

\author{
Vladislav Pogrebnoi ${ }^{1}$, Lyudmila Samorodova ${ }^{2}$, Larisa Shut'ko ${ }^{2}$, Yulia Yakunina $^{2}$, and \\ Oleg Lyubimov ${ }^{3, *}$ \\ ${ }^{1}$ "Transport-Electroprivod" Ltd., Directorate, 6500000, Kemerovo, Russia \\ ${ }^{2}$ KuzSTU, Department of economics, 65000028 Vesennya st., Kemerovo, Russia \\ ${ }^{3}$ KuzSTU, Department of information and automated manufacturing systems, 650000 Kemerovo, 28 \\ Vesennya st., Russia
}

\begin{abstract}
The article deals with issues related to the development of innovative projects by engineering companies and effective marketing policy as a factor of increasing their competitiveness in the mining equipment market. The paper presents the results of the development of innovative technology in the segment of extensible belt conveyors. The necessity of marketing the innovative project is proved by the example of the development of technology for the production of the motor-drum of a belt conveyor with an adjustable drive on continuous current magnets by the engineering company "Transport-Electroprivod" (LLC). The authors consider the effective marketing strategy of an engineering company as an attractor of increasing demand for innovation and competitiveness in the mining equipment market. The methods of marketing promotion and promotion of innovations are considered within the framework of the ecosystem concept of J. Moore.
\end{abstract}

\section{Introduction}

In modern conditions, engineering companies are actively developing in the Kuzbass market, promoting innovative technologies in the production of mining equipment. An example of successful promotion of innovative projects in the mining equipment market is the activity of the group of companies "Transport-Electroprivod". The own production of the group of companies "Transport-Electroprivod" is provided by the plants in cities Kemerovo and Topki, which produce conveyors and conveyor systems of all types and sizes, as well as building metal structures and various tanks, including high pressure.

Management of innovative projects of the engineering company involves solving a whole range of issues related to the feasibility study of the proposed technological solutions and ensuring competitiveness. Along with technical solutions, one of the important problems of the competitiveness of engineering companies is the marketing promotion of

*Corresponding author: oleg_lyubimov@mail.ru 
technological innovations in the mining equipment market in conditions of insufficient demand for innovations in the field of coal mining [4-8].

\section{Materials and Methods}

One of the latest innovative projects of LLC "Transport-Elektroprivod" was a project related to the development of a motor-drum model of a belt conveyor with an adjustable drive on continuous current magnets, in introduction of which the developers face the inadequate demand for an innovative product. of:

The development of this project is aimed at improving the conveyor systems in terms

- improving ergonomics (by reducing the size of the drive station), in mine conditions this is one of the most important requirements;

- Increasing the operational reliability of the conveyors (exception of additional nodes and mechanisms in the chain "transmission of driving torque from the motor", which in turn may fail, removing from the operating state the entire drive group, namely: reducer, underframe or lantern, reactive traction, turbo coupling, elastic clutch, delivered brake, low-speed half couplings and electric motor);

- reducing the costs of the enterprise as a result of the exclusion of the above components from the drive unit to the reserve funds for the organization of consignment warehouses (spare parts) and service from five, six suppliers of this equipment. Nowadays, at least five or six suppliers of components with which it is necessary to sign contracts are involved in the structure of the drive units (with each one, if possible, to sign service agreements, perform an audit, etc.), which is quite costly for the enterprise -producer;

- increasing the labor safety of miners (by reducing the rotation elements in drive unit);

- reducing the time and costs of installing the drive unit;

- the absence of special requirements for the surface on which the drive unit is installed, because the only supporting structure is the frame on which the motor-drum is located;

- the opportunities, in combination with management system, based on a frequency converter to save electricity by automatically reducing the speed at the time of absence or reduction of the volume of the rock mass on the conveyor, as well as transporting people at a safe speed of $3.15 \mathrm{~m} / \mathrm{s}$ according to the Safety Rules.

\section{Results and Discussion}

Together with foreign and Russian colleagues, the element base of the product and the performance specification were developed. The technical characteristics of the motor-drum are presented in Tab.1.

Table 1. The technical characteristics of the motor-drum.

\begin{tabular}{|c|c|c|c|}
\hline $\begin{array}{c}\text { Nominal power of } \\
\text { electric motor, } \mathbf{k W}\end{array}$ & Belt speed, $\mathbf{m} / \mathbf{s}$ & $\begin{array}{c}\text { Drum rotation } \\
\text { frequency, } \mathbf{r p m}\end{array}$ & $\begin{array}{c}\text { Torque rating, } \\
\mathbf{k N} / \mathbf{~ m}\end{array}$ \\
\hline \multicolumn{4}{|c|}{ Diameter of the drum $800 \mathrm{~mm}$} \\
\hline \multirow{3}{*}{$\begin{array}{c}\boldsymbol{P}=\mathbf{2 5 0} \mathbf{~ k W} \\
(\boldsymbol{n}=\mathbf{1 5 0 0} \mathbf{~} \boldsymbol{p m})\end{array}$} & 1.25 & 30 & 80 \\
\cline { 2 - 4 } & 1.6 & 37.5 & 62.2 \\
\cline { 2 - 4 } & 2.0 & 47.6 & 50 \\
\cline { 2 - 4 } & 2.5 & 60 & 40 \\
\cline { 2 - 4 } & 3.15 & 75 & 25 \\
\hline
\end{tabular}


It is planned to install this equipment in a belt conveyor $\mathrm{L}=1250$ meters. The rated belt speed is $4.0 \mathrm{~m} / \mathrm{s}$. The frequency-controlled drive must provide a change in speed from the nominal in the range "+" or "-" $20 \%$.

The carried out development and designed work revealed the competitive advantages of the developed innovative motor-drum model in comparison with the available models in terms of technical characteristics and price. The technical characteristics of the precalculated motor-drums with liquid cooling are given in Tab. 2.

Table 2. The technical characteristics of the proposed motor drums.

\begin{tabular}{|l|c|c|c|}
\hline \multirow{2}{*}{$\begin{array}{c}\text { Specifications } \\
\text { and parameters }\end{array}$} & \multicolumn{3}{c|}{ Options } \\
\cline { 2 - 4 } & 1 & 2 & 3 \\
\hline Power on shaft, kW. & 785 & 314 & 160 \\
\hline Frequency of rotation, rpm. & 60 & 60 & 73 \\
\hline $\begin{array}{l}\text { Haпряжение ceти, 50 Гц, кB } \\
\text { Voltage, 50 Hz, kV }\end{array}$ & 6 & 6 & 6 \\
\hline Amplitude of phase voltage pulse, $\mathrm{kV}$ & 1.0 & 1.0 & 1.0 \\
\hline Frequency of phase voltage, Hz & 60 & 40 & 36.5 \\
\hline Rated torque, kNm & 125 & 50 & 21 \\
\hline Efficiency is not lower & 0.97 & 0.97 & 0.96 \\
\hline Multiplicity of the starting torque & 2.0 & 2.0 & 2.0 \\
\hline Diameter of motor-drum, mm & 1250 & 1000 & 650 \\
\hline Length of motor-drum, mm & 1600 & 1400 & 1250 \\
\hline Number of phases & 6 & 6 & 6 \\
\hline Number of packages & 2 & 2 & 2 \\
\hline Number of parallel branches & 2 & 2 & 1 \\
\hline Number of poles & 18 & 12 & 9 \\
\hline Number of stator / rotor teeth & $54 / 60$ & $36 / 40$ & $27 / 30$ \\
\hline Specific force, N/cm2 & 4.2 & 4.0 & 4.8 \\
\hline Degree of protection of motor-drum & IP54 & IP54 & IP54 \\
\hline Weight of electrical steel, kg & 6000 & 3800 & 1800 \\
\hline Weight of electrical copper, kg & 560 & 350 & 270 \\
\hline Total weight of electrical steel and copper, kg & 6560 & 4150 & 2070 \\
\hline
\end{tabular}

The method of expert assessments revealed that in result of excluding the above components, the engine mass could be reduced by about $10 \%$, and calculations showed a reduction in drive unit price.

As a result of the correlation analysis performed with the help of software package, it was revealed the following:

- practically proportional dependence in price structure of the share of used electric motor on the diameter of the drum (and, accordingly, its price share);

- close correlation in price structure of the shares of the selected gearbox size and the adopted control system;

- reduction in the share of couplings and brake devices in price structure with an increase in the diameter of the drum;

- insignificant share of metal structures, supports and fasteners in price structure.

The analysis showed convincing superiority in price of the composed motor-drum in comparison with the standard drive unit, which consists of many costly components.

The third stage - perspective - the development of an innovative project - preparation of production and power ascension, i.e. manufacturing of products, which includes arrangements for a new product output. To implement this project, "TransportElektroprivod" LLC cooperates with Russian enterprises that have government orders for prototypes of motor-drums, and work under the orders of the Defense Ministry of the Russian Federation. 
The fourth stage of the innovative project is the production of the products created in accordance with the orders' portfolio. In this connection, the concept of the ecosystem by J. Moore is of interest. "For the implementation of any innovation, we need partnerconsumers and partner-suppliers. And the more radical (and often more valuable) innovation is, the more deeper and wider should be other players, especially consumers involved" [9]. Thus, to promote innovation successfully, cooperation with potential consumers is needed at the stage of development an innovation system.

In addition, it is at this stage that market research is needed, identifying potential consumer companies and promoting the product to the market. Preliminary monitoring of the Russian market of motor-drums for underground conveyors allowed to develop three variants of the forecasted market situation and to obtain the following results regarding potential demand, which is described in Tab. 3.

Table 3. The main technical and economic characteristics of motor-drums market for the underground conveyors in Russia.

\begin{tabular}{|l|c|c|c|c|}
\hline \multirow{2}{*}{\multicolumn{1}{|c|}{ Indicators }} & \multirow{2}{*}{ Units } & \multicolumn{3}{c|}{ Options } \\
\cline { 3 - 5 } & & 1 & 2 & 3 \\
\hline Conveyor Belt Width & $\mathrm{mm}$ & 1000 & 1200 & $1400 / 1600$ \\
\hline Average number of conveyors & $\begin{array}{c}\text { Units } \\
\text { Annually }\end{array}$ & 25 & 15 & 3 \\
\hline Typical power of the drive unit & $\mathrm{kW}$ & 160 & 315 & 500 \\
\hline Rated drum speed & $\mathrm{rpm}$ & 75 & 75 & 60 \\
\hline Drum Diameter & $\mathrm{mm}$ & 630 & 800 & 1250 \\
\hline Total number of drives & Units & 75 & 45 & 9 \\
\hline $\begin{array}{l}\text { The expected percentage of the market share } \\
\text { of motor-drums of the total number of drives }\end{array}$ & Percent & 35 & 60 & 70 \\
\hline Expected volume of motor-drums market & $\begin{array}{c}\text { Units } \\
\text { Annually }\end{array}$ & 20 & 40 & 30 \\
\hline
\end{tabular}

At the first stage the investments in this area (production of a pilot set of products) will be carried out entirely by LLC «Transport-Electroprivod». The cooperation with partner companies will allow LLC «Transport-Electroprivod» to purchase semi-finished products that will undergo further refinement and screwdriving assembly and certify the finished product.

The fifth stage - the operational period of the project - requires an effective marketing strategy, because the demand for this innovative product must be formed.

At the moment, LLC «Transport-Electroprivod» does not have an established system of marketing innovation in the mining equipment market. It is necessary to generate demand for innovations, because there is a certain inertia and stereotypes of engineering thinking of specialists in coal companies, restraining their introduction into production, due to the increased danger of mining operations. Overcoming this barrier, «Transport-Electroprivod» will have the opportunity to engage in further market research, look for potential consumers, etc.

Within the framework of the chasm theory by G. Moore, the most important in modern conditions is not the existence of two "cracks" in the life-cycle curve of technology: one between innovators and early followers, the other between the early and late majority, but the "deep chasm that divides early followers and an early majority. Today, this is the most significant and complex transition in the life cycle of technology adoption, and it is becoming increasingly dangerous, since it is usually not recognized "[10]. 
Of particular importance is a trusted image of an innovative product in the eyes of consumers, and it is necessary to accumulate confidence in product from the consumer's part. In addition, the innovator enterprise should determine the marketing channel for an innovative product, choosing between its own distribution network and marketing through intermediaries. In this case, it is advisable for «Transport-Elektroprivod» not only to use direct contracts, but also to combine sales channels, as the enterprise is included in the integrated group of companies, represented in the domestic and foreign markets of mining equipment. Undoubted competitive advantage of the company in the promotion of innovations will be the system of "smart service", which allows providing service of innovative equipment from the moment of delivery and installation of equipment up to its disposal. In Kuzbass there is an experience of successful use of "smart service" as an innovative service system for mining companies [11].

\section{Conclusion}

Along with traditional marketing methods (specialized exhibitions, expositions, demonstrations, transfer of equipment for trial operation, personal work with potential clients), we suggest methods of promotion based on the ideas of the chasm theory by G. Moore, his technique "test in the elevator", the use of an innovative system "smart service", the combination of sales channels. These methods will contribute to the formation of a trusted image of innovative goods in the eyes of consumers, and stimulate the demand for innovation.

\section{References}

1. "Transport-Elektroprivod" Ltd. has partner relations with Russian engineering companies, URL: https://piter-expo.ru/ru/engineering/

2. M.A. Tyulenev, S.A. Zhironkin, O.I. Litvin, E.A. Tyuleneva, O.V. Zhironkina, S.O. Markov, Geotech. Geol. Eng. 35:5, 2065-2077 (2017)

3. M. Tyulenev, S. Zhironkin, E. Tyuleneva, A. Abay, S. Anyona, M. Hellmer, Coal Int., 265:3, 30-34 (2017)

4. A. Amosha, B. Birenberg, A. Kabanov, Methods of managing innovative processes in Ukranian coal industry (Donetsk, Mining, 1999)

5. S. Valdaytsev, Technological innovations management (Saint-Petersburg, 2004)

6. Yu. Fridman, G. Rechko, Ye. Loginova, Vestnik KuzSTU, 6, 139 (2013)

7. I. Gurkov, Ye. Avraamova, V. Tubalov, Econ. Iss., 2, 40 (2005)

8. C. Christensen, M. Raynor, The innovator's solution creating and sustaining successful growth (Harvard, 2004)

9. J. Moore, The Death of Competition (NY, 1996)

10. J. Moore, Crossing the Chasm: Marketing and Selling Technology Products to Mainstream Customers (NY, 1998)

11. L. Samorodova, L. Shut'ko, Yu. Yakunina, O. Lyubimov, E3S Web of Conf., 15, 03013 (2017) 
